\title{
Synthesis of Diamino Benzoquinones using Facile and One-Pot Chemical Oxidative Method
}

\section{MOHSEN SARGORDAN ARANI* and NILOOFAR BIGDELI}

Department of Chemistry, Faculty of Science, Yadegar-e-Imam Khomeini (RAH),

Shahre Rey Branch, Islamic Azad University, Tehran, Iran.

*Corresponding author E-mail: mohsenfard555@yahoo.com

http://dx.doi.org/10.13005/ojc/320635

(Received: August 27, 2016; Accepted: October 23, 2016)

\begin{abstract}
An efficient synthesis of diamino benzoquinone, beginning from catechol derivatives and hydroquinone with azide ion was developed in the presence of potassium ferricyanide as an oxidizing agent (Decker oxidation), the results of which revealed the participation of azide ion in Michael addition reactions with benzoquinones yield in situ. This study has made one-pot oxidative method possible for diamino benzoquinones synthesis.
\end{abstract}

Keywords: Catechol, Hydroquinone, Sodium azide, Diamino Benzoquinone, Michael reaction.

\section{INTRODUCTION}

Of the nuisances the chemists are facing in organic chemistry is to develop some simple and efficient chemical processes and methods for synthesizing the extensively applied organic compounds from easily available reagents. Quinones based amino derivatives, considered as the critical constituents in synthesizing a wide variety of natural products, medicinal compounds ${ }^{1-4}$ applying antitumor and antimalarial activities ${ }^{5-8}$ are typically supplied by alternative, multistep synthetic pathways ${ }^{9}$.

In addition, the derivatives known as the ortho benzoquinone haven't been studied much compared with those of the para-benzoquinone since it is usually hard to prepare them in rather moderate yields ${ }^{10}$. In this respect, as far as our we know, in the past no in situ chemical oxidation reaction of benzoquinones using azide ion (3) has been reported while the electro-oxidation of catechol and hydroquinone with ion azide has been previously reported ${ }^{11,12}$. As stated, this way we have made a facile and one-pot synthesis for diamino benzoquinones available that employs catechols derivatives $3(\mathrm{a}-\mathrm{c})$ or hydroquinone chemical oxidation (1) with azide ion using potassium ferricyanide as an oxidizing agent (Decker oxidation) resulting in high purity and yield.

\section{RESULTS AND DISCUSSION}

Comparing the $\mathrm{E}_{0}$ values based on the evaluation of the midpoint potential between 
the anodic and cathodic peaks $\left(E_{\text {mid }}\right)$ for catechol $[(0.12+0.07) / 2=0.165]$, hydroquinone $[(0.19+0.03) / 2=.0 .08]$ and potassium ferricyanide $[(0.24+0.15) / 2=0.129]$ displayed that $\mathrm{Fe}(\mathrm{CN}) 6^{3-}$ is an appropriate agent to mildly oxidize catechol or hydroquinone using ion azide ${ }^{13,14}$. Thus to oxidize catechol (4) and hydroquinone employing azide ion as a nucleophile has been surveyed. In terms of the mechanism, as shown the Michael addition reaction of azide ion to $p$-benzoquinone (1a) seemingly brings about the intermediate (1b). The following phase deals with azido-benzoquinone (1b) conversion into amino benzoquinone (1c) using an intramolecular oxidation-reduction reaction. After that, $1 \mathrm{c}$ is converted into $1 \mathrm{~d}$ by Michael addition and intramolecular oxidation-reduction reactions, followed by diamino-o-benzoquinone 2 as the resulting product $(80 \%$ isolated yield).

Based on the mechanism explained above, the compounds $3(\mathrm{a}-\mathrm{c})$ can be converted into 4(a-c). The overall reactions can be described as depicted in Scheme 2.

\section{EXPERIMENTAL}

Generally, all of the reagents and solvents were selected from the reliable grade. The melting points were determined in Bamstead electrothermal B4300 system open capillaries. THERMO ICO TNEXUS 870-FT spectrometer with $\mathrm{KBr}$ pellets was used to measure IR Spectra, reported in $\mathrm{cm}^{-1}$. And NMR spectra were measured by a Bruker DPX $300 \mathrm{MHz}$ spectrometer in DMSO-d 6 with chemical shift given in ppm compared with TMS as the internal standard. Mass spectra were obtained with Thermofinnigan MAT95XL spectrometer system. The related data were tabulated as $\mathrm{m} / \mathrm{z}$. Thermofinnigan Flash EA 1112 instrument was used for the analyses of the elements.

\section{General Synthesis Method}

To a stirred solution of aqueous (ca50 mL) of acetate buffer ( $\mathrm{pH} 5.0,0.2 \mathrm{M}), 2 \mathrm{mmol}$ of catechol [3(a-c)] or hydroquinone (1), and $10 \mathrm{mmol}$ of sodium azide were added and dissolved. In a dropping funnel in the question solution, potassium ferricyanide (4 mmol) was added dropwise within 20-30 min. The reaction mixture was kept at room temperature, occasionally stirred for $1 \mathrm{~h}$ (about hydroquinone, for 4-5 h). After that the solution got dark and some precipitates appeared. As the final stage of the reaction, the round-bottom flask was kept at $40^{\circ} \mathrm{C}$ overnight (about hydroquinone, it was kept at $45^{\circ} \mathrm{C}$ for 4-5 h). Filtration was used to collect the precipitated solid washed with water after that.
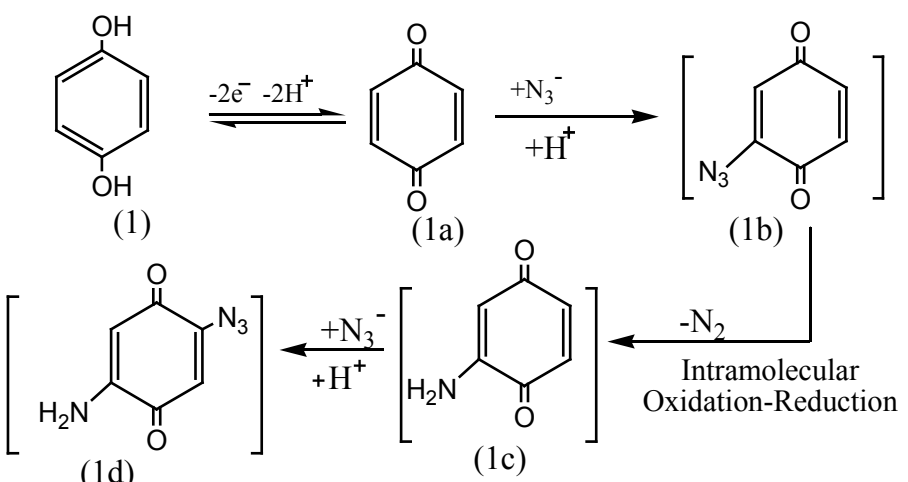

(1d)

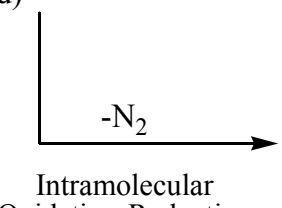
Oxidation-Reduction<smiles>NC1=CC(=O)C(N)=CC1=O</smiles>

(2)

Scheme 1: hydroquinone oxidation mechanism and its reaction with sodium azide 
<smiles>N#CC(C#N)CC1CCCCC1</smiles>

(1)<smiles>NC1=CC(=O)C(N)=CC1=O</smiles>

(2)

$$
\begin{aligned}
& \mathrm{Fe}(\mathrm{CN})_{6}^{3-}, \mathrm{N}_{3}^{-} \\
& -\mathrm{N}_{2}
\end{aligned}
$$

\section{Scheme 2: Overall catechols derivatives and hydroquinone oxidation reaction using azide ion}

4,5-diaminocyclohexa-3,5-diene-1,2dione $\left(4 \mathrm{a}, \mathrm{C}_{6} \mathrm{H}_{6} \mathrm{~N}_{2} \mathrm{O}_{2}\right): 85 \%$; violet crystals ;M.p.: $300{ }^{\circ} \mathrm{C}$; 'HNMR: (500 MHZ, acetone-d6): $\delta=7.36$ (broad, 4H) 5.29 (s, 2H) ppm; ${ }^{13} \mathrm{CNMR}(500 \mathrm{MHZ}$, DMSO-d6): $\delta=178.8 .153 .3,98.7 \mathrm{ppm}$; IR (KBr) $\bar{\nu}$ $=3421,3276,3063,1729,1693,1594,1515,1470$, $1343,1294,834,748,670 \mathrm{~cm}^{-1}$; MS $(70 \mathrm{eV}):(\mathrm{m} / \mathrm{z})=$ $138\left(\mathrm{M}^{+}, 100\right), 121(10), 111$ (16),110(60), 94(30), 83(45),68(85)

2, 5-diaminocyclohexa-2, 5-diene-1, 4-dione (2, $\mathrm{C}_{6} \mathrm{H}_{6} \mathrm{~N}_{2} \mathrm{O}_{2}$ ): $71 \%$; violet crystals ;M.p.: $380^{\circ} \mathrm{C}$; ${ }^{1} \mathrm{HNMR}$ : (500 MHZ, acetone-d6): $\delta=7.32$ (br s, 2H NH), 6.95 (br s, 2H NH), 5.32(s, 2H) ppm; ${ }^{13} \mathrm{CNMR}$ (500 MHZ, DMSO-d6): $\delta=179.21,154.45$, 95.45 ppm; IR $(\mathrm{KBr})=3352,3120,1663,1534$, $1418,1257,1061,843 \mathrm{~cm}^{-1} ; \mathrm{MS}(70 \mathrm{eV}):(\mathrm{m} / \mathrm{z})=138$ $\left(\mathrm{M}^{+}, 100\right), 121(10), 110$ (50),94(30), 83(46), 68(70), $41(80)$.

4, 5-diamino-3-methylcyclohexa-3, 5-diene-1, 2-dione (4b, $\left.\mathrm{C}_{7} \mathrm{H}_{8} \mathrm{~N}_{2} \mathrm{O}_{2}\right): 79 \%$; violet crystals ;M.p.: $280^{\circ} \mathrm{C}$; 'HNMR: (500 MHZ, acetone-d6): $\delta=7.39$ (br s, $4 \mathrm{H} \mathrm{NH}), 5.28(\mathrm{~s}, 1 \mathrm{H})$, $1.89(\mathrm{~s}, 3 \mathrm{H}) \mathrm{ppm} ;{ }^{13} \mathrm{CNMR}$ (500 MHZ, DMSO-d6): $d=180.8,178.41,153.1,97.2,95.1,9.3 \mathrm{ppm} ; \mathrm{IR}$ $(\mathrm{KBr})=3400,3236,3063,1723,1514,1470,1343$, $1104 \mathrm{~cm}^{-1} ; \mathrm{MS}(70 \mathrm{eV}):(\mathrm{m} / \mathrm{z})=152\left(\mathrm{M}^{+}, 100\right), 137(35)$, 97 (60), 83(50), 69(80), 56(45), 15(80) ; Anal. Calcd: C, 55.26; H, 5.30; N, 18.41; O, 21.03\% .Found: C, $56.25, \mathrm{H}, 5.02, \mathrm{~N}, 17.66 \%$.
4, 5-diamino-3-methoxycyclohexa-3, 5-diene-1, 2-dione (4C, $\mathrm{C}_{7} \mathrm{H}_{8} \mathrm{~N}_{2} \mathrm{O}_{3}$ ): $75 \%$; violet crystals;M.p.: $295^{\circ} \mathrm{C}$; ${ }^{1} \mathrm{HNMR}$ : (500 MHZ, DMSO-d6): $\delta=7.36(\mathrm{br} \mathrm{s}, 4 \mathrm{H} \mathrm{NH}), 5.27(\mathrm{~s}, 1 \mathrm{H}) 3.88(\mathrm{~s}, 3 \mathrm{H}, \mathrm{OMe})$, ppm; ${ }^{13} \mathrm{CNMR}$ (500 MHZ, DMSO-d $)_{6}$ : $\delta=178,175$, 160, 154, 138, 99, 56 ppm; IR $(\mathrm{KBr})=3376,3327$, 3067, 1693, 1585, 1515, 1466, 1347, $1241 \mathrm{~cm}^{-1}$; Anal. Calcd: C, 50.00; H, 4.80; N, 16.66. Found: $\mathrm{C}, 51.15, \mathrm{H}, 4.62, \mathrm{~N}, 17.06 \%$.

\section{CONCLUSION}

In the current research, the chemical oxidization of hydroquinone and catechol derivatives in the presence of sodium azide in one- pot has been analyzed for diamino benzo quinone derivatives synthesis. The resulted benzo quinone derivatives cannot be easily and during one- pot produced via other methods. This can clarify the importance of the task. The abundant applications of diamino benzo quinone open a horizon to us that this method can be expanded for similar compounds.

\section{ACKNOWLEDGEMENT}

I sincerely appreciate Prof. Davood Nematollahi for the posed discussions and for his practical suggestions in this work. 


\section{REFERENCES}

1. Joyner, P. M.; Cichewicz, R. H. Nat. Prod. Rep. 2011, 28, 26" 47.

2. Monks, T. J.; Jones, D.; Drug Metab. 2002, 3, 425 "438.

3. Lin, P.; Li, S.; Wang, S.; Yang, Y.; Shi, J. J. Nat. Prod. 2006, 69, 1629 “ 1632.

4. McErlean, C. S. P.; Moody, C. J. J. Org. Chem. 2007, 72,10298 .

5. Mondal, P.; Roy, S.; Loganathan, G.; Mandal, B.; Dharumadurai, D,; Akbarshah, M.A.; Sengupta, P.S.; Chattopadhyay, G.; Dhanasekaran, B. Biochem. Biophys. Reports. 2015, 4, 312-323.

6. Nemeikaitë-Ëënienë, A.;Jaraðienë, R.; Nivinskas, H.; Đarlauskas, J.; Ėënas, N .chemija. 2015, 26, 1, 46-50.

7. Marra, R. K.F.; da Silva, F. de. C.; Resende, J. s. A.; de Silva,L.C. L. F. R.; Alves, H.G.; Barbosa, G. S.; de Vasconcellos, M.C.; lima, E. S.; pohlit, M. A.; Ferreira, V. F. Eur.J.Med.
Chem. 2016. 108. 134-140.

8. Ghorab, M. M.; Alsaid, M. S.; El-Gazzar, M.G.; Higgins, M.;Dinkova-Kostova, A. T.; Shahat, A. A. J. Enzyme. Inhib. Med. Chem.2016, 1-6.

9. a) Moore. H. W.; Shelden. H. R.; Deters, D. W.; Wikholn, R. j. J. Am. Chem. Soc. 1970, 92, 1675. b) Ma, H. C.; Jiang, X.Z. Syn. Let. 2007, 11, 1679 - 1682.

10. Kashima, C.; Tomotake, A.; Omote, Y. J. Org. Chem. 1987, 52, 5616.

11. Nematollahi, D.; Afkhami, A.; Tammari, E.; Shariatmanesh, T.; Hesari, M.; Shojaeifard, M. Chem. Commun. 2007, 2, 162.

12. Nematollahi, D.; Khoshsafar H . Tetrahedron. 2009, 65, 4742

13. Nematollahi, D.; Habibi, D.; Alizadeh, A.; Hesari, M. J. Heterocyclic. chem . 2005, 42, 289.

14. Nematollahi, D.; Amani, A.; Tammari, E. J. Org. Chem. 2007, 72, 10, 3646. 